
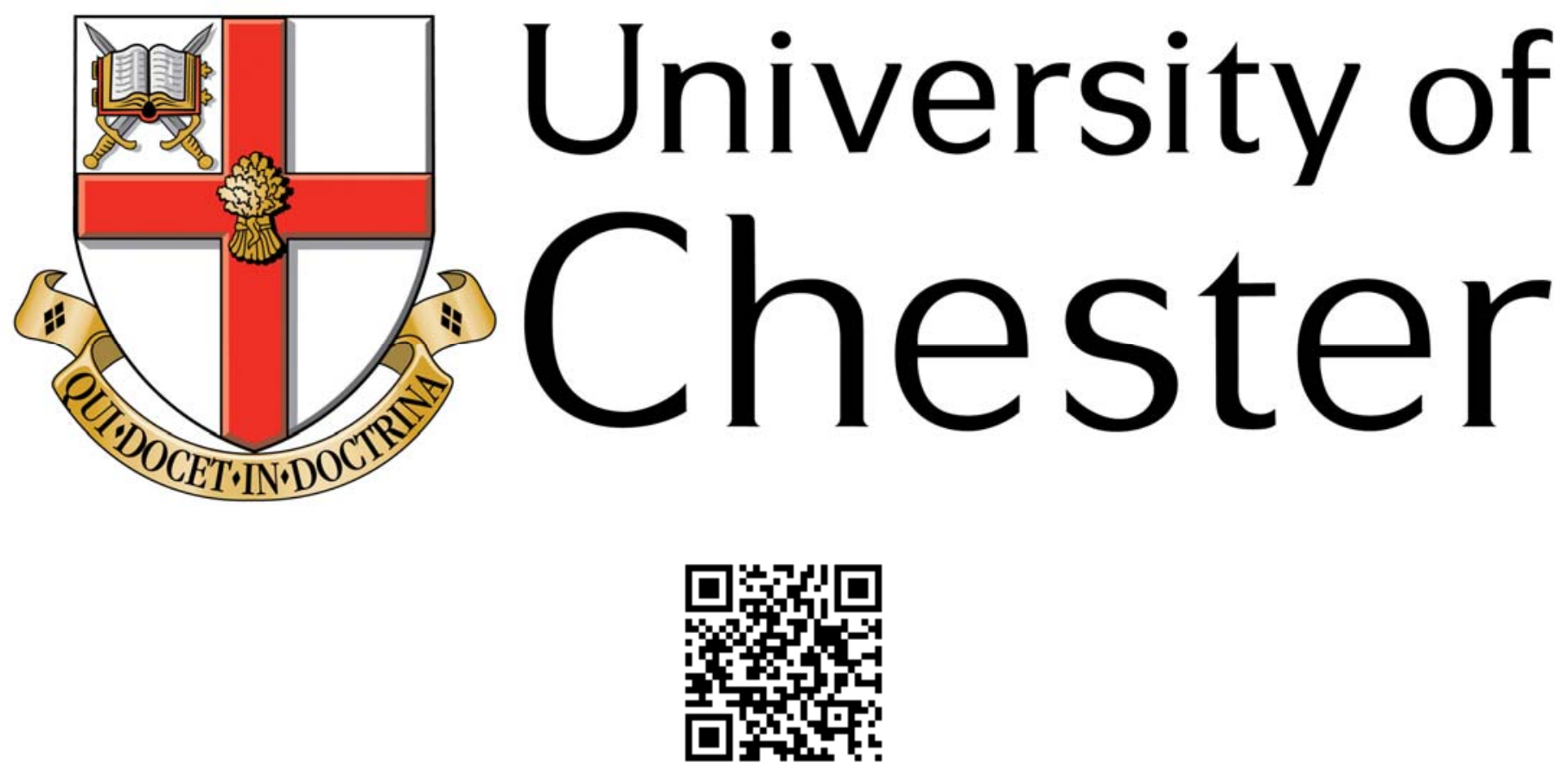

This work has been submitted to ChesterRep - the University of Chester's online research repository

\title{
http://chesterrep.openrepository.com
}

Author(s): Gill Henwood

Title: Is equal marriage an Anglican ideal?

Date: May 2015. Appeared online 1 December 2014

Originally published in: Journal of Anglican Studies

Example citation: Henwood, G. (2015). Is equal marriage an Anglican ideal? Journal of Anglican Studies, 13(1), 92-113. http://dx.doi.org/10.1017/S1740355314000229

Version of item: Authors post-print

Available at: http://hdl.handle.net/10034/335802 


\title{
Is Equal Marriage an Anglican Ideal?
}

\begin{abstract}
A critical conversation between the Church of England's response to the Government's consultation on Equal Civil Marriage 2012, questions arising from professional parish practice as a priest, and literature in this area of research. The article explores the theological significance of 'equal marriage' (equal access to marriage and equality within marriage) as a Christian possibility within the Church of England, with contemporary approaches to gender and sexuality.
\end{abstract}

Keywords: civil partnership; complementarity; equal marriage; gay marriage; gender; marriage; sexuality.

The Rev'd Gill Henwood

Department of Theology and Religious Studies

University of Chester 


\section{Is Equal Marriage an Anglican Ideal?}

\section{Introduction}

In this article, the official response from the Church of England to the UK Government's consultation on equal access to civil marriage in 2012 is brought into conversation with literature informing the debate and my experience from ordained parish practice since 1997, including membership of General Synod 2005-9. The process and issues arising raise the questions, what might equal marriage be, and can it be an Anglican ideal?

Not long ago I received an email enquiry from a local couple requesting marriage in our church. They wrote, 'We are gay partners. I know the church has very mixed views on this subject. Perhaps if a wedding is not appropriate you could offer some sort of blessing?' The Church of England position is that 'we as a body cannot support the authorization of such rites'. ${ }^{1}$ As incumbent of a benefice, I am not permitted to officiate at a same-sex wedding or a service of blessing after civil partnership. The challenge was to find a pastoral response to welcome my two parishioners and keep within the law of the Church of England. My two strands of enquiry were how to provide a liturgy that was affirming and celebratory whilst also legal and how to engage with official Church of England teaching. This article explores the second strand, my formal theological enquiry, offering a 'subaltern voice'2 through a new synthesis where 'practices of faithful Christian people are themselves already the bearers of theology; they express the contemporary living tradition of the Christian faith' ${ }^{3}$

\footnotetext{
${ }^{1}$ Church of England, 'Civil Partnerships - A pastoral statement from the House of Bishops of the Church of England', (London, 25 July 2005), para. 16.

2 R. Ruard Ganzevoort, 'Narrative Approaches' in Bonnie J. Miller-McLemore (ed.), The Wiley-Blackwell Companion to Practical Theology (Chichester: Wiley-Blackwell, 2012), pp. 214-223 (214).

${ }^{3}$ H. Cameron, D. Bhatti, C. Duce, J. Sweeney and C. Watkins, Talking about God in Practice: Theological Action Research and Practical Theology (London: SCM, 2010), p. 51.
} 
In Stephen Pattison's discussion on practical theology (PT), he advocates 'taking a wide view of the world and engaging with big questions such as...the possibilities of human development'. ${ }^{4}$ Pattison asserts that practical theology 'should be at the forefront of new understandings of what it is or might be to be human'. ${ }^{5} \mathrm{He}$ argues that practical theology as 'a confessional science of the human spirit' has the capacity to change as well as to understand the world and that 'PT should seek to be transformational. ${ }^{6}$ In this paper, I engage as a practical theologian with active questions arising from my professional practice where I encounter the possibility of human transformation through relationships between two people in the light of God's presence.

Since ordination as a priest in 1998, pastoral encounters continue to challenge me to reflect on issues demanding significant changes in the Church of England's normative theology. A subject that 'really matters to people' in public debate is equality, focused in 2012-13 on equal access to civil marriage. Through questioning and a sceptical stance, my intention is to test the robustness of the Church's official response to the government, ${ }^{7}$ seeking signposts for the possibility of a new understanding of equal marriage as an Anglican ideal.

\section{The Response from the Church of England to the Government Consultation on Equal Civil Marriage 2012}

From March to June 2012 the UK Government consulted 'on how to provide equal access to civil marriage for same-sex couples' in England and Wales and stated that there would be no legal requirement for religious

\footnotetext{
4 Stephen Pattison, 'Practical Theology: Art or Science?' The Challenge of Practical Theology: Selected Essays (London: Jessica Kingsley, 2007), pp. 261-289 (277).

5 Pattison, 'Practical Theology', p. 279.

${ }^{6}$ Pattison, 'Practical Theology', pp. 283-284.

${ }^{7}$ Carolyn Taylor and Stephen Hicks, Achieving your Professional Doctorate: A Handbook (Maidenhead: Open University Press, 2009), p. 54.
} 
organizations to offer equal access to marriage, although they could do so. ${ }^{8}$ In the government's summary in December specific protection, a 'quadruple lock', was proposed for the Church of England within the UK, to avoid legal action by same-sex couples for discrimination. ${ }^{9}$ This is because heterosexual couples have legal rights to marry in certain parish churches in England. ${ }^{10}$

The opening sentence of the national Church's response states: 'The Church of England cannot support the proposal to enable "all couples, regardless of their gender, to have a civil marriage ceremony".'11 Arguing that marriage is the same institution for all, with only the ceremony differing between a secular or religious rite and venue, the response asserts a single understanding of marriage. There is no discussion, for example, of marriage understood as a civil contract or as a Christian sacrament, and no recognition that there are legally-defined differences, considered in a later section of this article. The government's consultation summary acknowledges 'the Canon law understanding of marriage (Canon B30), which we accept will be narrower than that of the civil law'. ${ }^{12}$ If the proposed legislation is enacted, there will be two different understandings of marriage: a narrower, traditional, Church of England version in canon law and a broader, secular version in civil law.

The Church's response argues that to redefine marriage is beyond the competency of any government, ${ }^{13}$ disagreeing with the proposals for three reasons: the intrinsic nature of marriage; the benefits of marriage to society;

\footnotetext{
${ }^{8}$ Government Equalities Office, 'Equal civil marriage: a consultation', (London: Crown copyright, March 2012).

${ }^{9}$ Government Equalities Office, 'Equal Marriage: The Government's Response. December 2012', (London: Crown copyright, Version 1.1 February 2013).

${ }^{10}$ Government Equalities Office, 'Equal Marriage: The Government's Response', p. 17, para. $4.19,4.20$

${ }^{11}$ Church of England, 'A Response to the Government Equalities Office Consultation - "Equal Civil Marriage"- from the Church of England', (June 2012).

12 Government Equalities Office, 'Equal Marriage: The Government's Response', p. 18, para. 23.

${ }^{13}$ Church of England, 'A Response', para. 8.
} 
and the institution of marriage. ${ }^{14}$ This raises questions over the role of Parliament and the Church of England's General Synod in the formation of national law, civil and canon respectively. The Church's response, whilst clarifying the legal requirement of canon law to be consonant with civil law, implies a challenge to the government over who may legislate on the nature of marriage. Measures approved by General Synod must be ratified by Parliament before submission for royal assent. ${ }^{15}$ However, there is no requirement for legislation approved by Parliament to be ratified by General Synod. The government's summary picks up these points: 'We do not dispute the Church's authority here; however it is equally true that Parliament is sovereign and can enact to take account of potential conflicts with the Canon law', citing the use of conscience and exemption clauses with regard to the remarriage of divorced people. ${ }^{16}$ As the pace of change and the division between legislative bodies widens, is there a risk that the Established Church is marginalizing itself and its voice, moving slowly towards disestablishment?

By rooting the Church's response in an assertion of an 'intrinsic nature' of marriage, ${ }^{17}$ there is an absence of dialogue with a significant body of research on human being and human relationships generated during the past fifty years. For the national Church to speak with authority, greater engagement is needed with theological issues: of human identity and relationship relating to marriage, and equality of relationship within marriage. A conversation between the Church's response, literature and practice follows in the next section.

Describing marriage as 'enshrined in human institutions', ${ }^{18}$ the Church of England's response fails to offer a Christian faith perspective of the

\footnotetext{
${ }^{14}$ Church of England, 'A Response', para. 6.

${ }^{15}$ Church of England, 'Same-sex Marriage and the Church of England, an Explanatory Note', (12 December 2012).

${ }^{16}$ Government Equalities Office, 'Equal Marriage: The Government's Response', p. 18, para. 4.22 .

${ }^{17}$ Church of England, 'A Response', para. 6.

${ }^{18}$ Church of England, 'A Response', para. 6.
} 
presence of God, within each spouse, between them in their marriage, and in the institution. In the pastoral practice of preparing couples for marriage, engagement with the Church of England's marriage liturgies fosters exploration of relationships between human and divine, which may resonate with their personal experience and illuminate the couple's understanding of marriage. ${ }^{19}$ By focusing on the human institutions, the Church of England's response risks missing the significance of the possibility of an experiential relationship between two people which is subsequently affirmed as marriage.

The response's assertion of an intrinsic nature of marriage enshrined throughout history ignores changes in practice and understanding over time. The theological question arises whether marriage as an institution, human and divinely inspired, has a continuing capacity to adapt. ${ }^{20}$ This may be tested through interpretation of the Scriptures and tradition as they resonate with contemporary human experience and academic research. For example, the Church's argument against change ignores the significant proportion of contemporary couples who choose not to marry, yet establish home together often with children. In 2012 there were 5.9 million people (11.7\%) cohabiting in the UK, double the 1996 figure (6.5\%). ${ }^{21}$ Contemporary couples may, therefore, be reforming the meaning of marriage from within their own experience and practice. The Church can choose to engage in public debate to explore this rapid change.

The Church's response summary argues that when legislation was debated for civil partnerships, 'we have supported changes... to remove unjustified discrimination and create greater legal rights for same-sex couples'. This

\footnotetext{
19 The Archbishops' Council, Common Worship: Pastoral Services (London: Church House Publishing, 2000), pp. 102-134.

${ }^{20}$ Stephanie Coontz in Adrian Thatcher, God, Sex and Gender (Chichester: Wiley-Blackwell, 2011), p. 85; Charlotte Methuen, 'Marriage: one man and one woman?'

http://opendemocracy.net/ourkingdom/charlotte-methuen/marriage-one-man-and-one-woman (12 April 2013).

${ }^{21}$ Office for National Statistics, 'Short Report: Cohabitation in the UK, 2012', (1 November 2012), p. 1.
} 
implies awareness that there continues to be discrimination and that the Church considers ongoing discrimination to be justified, because of the greater importance of a heterosexual intrinsic nature of marriage. ${ }^{22}$ The response welcomes the 'fact that previous legal and material inequities have now been satisfactorily addressed' but ignores the very real inequities remaining, now under public debate. The law at present permits a heterosexual couple to choose a civil or a religious marriage, whilst a homosexual couple can choose neither, but may choose a civil partnership. The proposed legislation would permit couples regardless of gender to choose a civil marriage and same-sex couples to choose a civil partnership.

The Church's response ignores the significant differences between entering into a civil partnership or civil marriage. The legal contract in a civil partnership is made when both parties sign a paper, after making declarations that they are legally free to do so. There is no requirement for vows or a ceremony, although these options are available from Council Registry Offices and, having no legal significance, may be adapted freely or written afresh. ${ }^{23}$ The legal contract in a civil marriage is formed when both make their vows before a registrar and witnesses, in the context of a ceremony. There are legal differences in the content of a civil and a religious ceremony; for example, neither civil marriages nor civil partnerships may include language referring to God, hymns, or religious music. The Church's response ignores the inequity for same-sex couples, their clergy, and communities who are not permitted to celebrate civil partnerships with any Anglican faith context or content.

After a civil marriage, a heterosexual couple may celebrate their union in An Order for Prayer and Dedication after Civil Marriage or a Thanksgiving for

\footnotetext{
22 'Heterosexuality and homosexuality are not equally congruous with the observed order of Creation or with the insights of revelation', in Church of England, 'Civil Partnerships - A pastoral statement', para. 6.

23 Bracknell Forest Registration Service. 'Your civil partnership ceremony choices', (2011).
} 
Marriage in the Church of England, ${ }^{24}$ during which their ring(s) may be blessed, they may affirm or renew their marriage vows and the marriage may be blessed when a priest officiates. These services are not permitted by the Church of England after civil partnerships. The Church's response to the government does not admit that the legal situation under canon law results in the refusal of any public form of blessing to civil partners and partnerships. Further, Church of England clergy are prevented from giving God's blessing, even when their conscience or the pastoral situation would lead them to offer this ministry. This refusal of God's blessing in public applies equally to practising clergy and laity who have entered into civil partnerships since 2005. The experience of some parish clergy and congregations is a growing sense of unease and injustice, that Christian blessing is being denied for parishioners who are esteemed in their communities. The Church's response omits any reference to, or acknowledgment of, Christian experience from those within the Church of England of civil partnerships that might inform the debate on equal access to civil marriage. The Church's response asserts that 'to change the nature of marriage for everyone will be divisive' and 'deliver no obvious legal gains given the rights already conferred by civil partnerships'.

\section{In Conversation}

In this section, questions arising from the Church of England's response to the British government consultation on equal civil marriage are brought into conversation with pertinent literature and professional practice. This quest for formal theological understanding explores two areas: the process of the debate on marriage; and issues of disagreement based on theological differences. The conversation notes four voices of theology: normative, meaning the official teaching, texts and liturgies of the Church of England; formal theological enquiry and dialogue with other disciplines; operant

\footnotetext{
24 The Archbishops' Council, Common Worship: Pastoral Services (London: Church House Publishing, 2000), pp. 173-193.
} 
theology within the practices of Christian groups; and espoused theology adopted within groups' articulated beliefs (see Figure 1.) ${ }^{25}$

Figure 1. THE FOUR VOICES OF THEOLOGY

\begin{tabular}{|c|c|}
\hline $\begin{array}{c}\text { NORMATIVE THEOLOGY } \\
\text { Scriptures, the Creeds, official } \\
\text { Church teaching, liturgical texts }\end{array}$ & $\begin{array}{c}\text { FORMAL THEOLOGY } \\
\text { The 'theology of theologians'; results } \\
\text { of dialogue with other academic } \\
\text { disciplines }\end{array}$ \\
\hline $\begin{array}{c}\text { ESPOUSED THEOLOGY } \\
\text { The theology embedded within a } \\
\text { group's articulation of its beliefs }\end{array}$ & $\begin{array}{c}\text { OPERANT THEOLOGY } \\
\text { actual practices of a group }\end{array}$ \\
\hline
\end{tabular}

\subsection{The Process of the Debate}

The Church's response evaluates the government's proposals for equal access to civil marriage as 'deeply unwise'. ${ }^{26}$ This judgement, arising from the normative theology of the Church of England, jars with the experience and operant theology of some Anglican Christians. There is discord between the Church's official response to the government and the responses of Changing Attitude, ${ }^{27}$ and of Inclusive Church, ${ }^{28}$ on behalf of Anglicans who support equal access to marriage. The divergence raises questions, about the authority of the Church's judgement, and the authenticity of experience and operant theology at grassroots level. A characteristic valued in the Church of England is a diverse range of churchmanship both catholic and reformed, where it is possible to hold in creative tension differences of theology and practice, recently regarding the remarriage of divorced people and the ordination and consecration of women. As the established national

\footnotetext{
${ }^{25}$ Cameron et al., Talking about God in Practice, p. 54.

${ }^{26}$ Church of England, 'A Response', Summary.

27 Changing Attitude, 'Submission to the House of Commons Committee Marriage (Same Sex Couples) Bill', (26 February 2013)

28 Inclusive Church, 'Equal Civil Marriage: A Consultation. Inclusive Church's response', (2012).
} 
church, can the Church of England bear witness to the varied experience of God's people, rather than perpetuate a single norm, continuing to exclude those whose humanity is different? How does the Church's response to the government consultation speak with authority, when there is an absence of congruence between the Christian witness of some Anglicans and the normative theology of their Church? May an official response on behalf of the Church of England state magisterially, 'We also believe that imposing for essentially ideological reasons a new meaning on a term as familiar and fundamental as marriage would be deeply unwise'? Who are 'we', when there are dissenting Anglican voices submitting responses to the government, including the opposite point of view: 'from our extensive parish and pastoral experience we believe the majority of members of the Church of England support equal marriage'?29 Are these voices offering a new wisdom, excluded by the official response?

In the cycle of reflective practice ${ }^{30}$ operant theology continuously informs espoused theology and, through formal theology (as well as via campaigning groups), can generate a momentum for the normative theology of the Church to shift. Anglican theology pays attention to God speaking through Scripture, tradition and reason integrated with human experience. This searching, reflective process requires prayerful listening and discernment: an active listening to God, including through the stories being told by contemporary human beings in relationship.

Constructive narrative theology proposes that humans use storytelling to create our world, and that God reveals the divine through stories. ${ }^{31}$ Theological reflection in this tradition is the creative interweaving of many strands of human experience and sacred tradition into exciting new configurations'. Stephen Crites describes how stories operate in three 'narrative tracks:' sacred; mundane; and narratives of human experience.

\footnotetext{
${ }^{29}$ Changing Attitude, 'Submission', para. 1.2.

30 Cameron et al., Talking about God in Practice, p. 54.

${ }^{31}$ Elaine Graham, Heather Walton and Frances Ward, Theological Reflection: Sources (London: SCM Press, 2007), pp. 88-89.
} 
These resonate with one another, revealing meaning and identity. ${ }^{32} \mathrm{He}$ recognizes that 'the vitalities of experience itself may in turn make a man [sic] feel that some of the old stories have a hollow ring and may be the source of originality in the formation of new stories'. The gap between the Church of England's response and 'the vitalities of experience' of people in, and of, same-sex relationships alerts us to the possibility that new stories are being forged, emerging from and about human relationships. The 'hollow ring' of the old certainties 'enshrined in human institutions' and the 'intrinsic nature of marriage' warns us to listen to contemporary narratives as a 'source of originality in the formation of new stories' which resonate afresh with the Christian narratives of the scriptures and tradition. A reflective practice of discernment and theological engagement does not pre-judge the outcome but, through intentional open-mindedness and structured conversations, provides a context where new connections may be made.

Crites recognizes the power within those three 'narrative tracks' when 'sometimes the tracks cross, causing a burst of light like a comet entering our atmosphere. Such a luminous moment, in which sacred, mundane and personal are inseparably conjoined, we call symbolic in a special sense. ${ }^{33}$ The ritual of marriage can act as a physical symbol and, resonating with the context, as a religious symbol. Crites explains that a physical symbol given meaning by the stories told about it may be experienced powerfully:

The shock of its appearance is like the recurrence in daylight of an episode recalled from dreams. For a religious symbol becomes fully alive to consciousness when sacred story dramatically intersects both an explicit narrative and the course of a man's [sic] personal experience. The symbol is precisely that double intersection.

The physical and religious symbol of marriage can be an example of a 'double intersection' of sacred story with the explicit narrative of marriage and the couple's personal experiences of reciprocal loving. Within marriage

\footnotetext{
32 Stephen Crites, 'The Narrative Quality of Experience', in Graham et al., Theological Reflection: Sources, pp. 96-113.

${ }^{33}$ Crites, in Graham et al., Theological Reflection: Sources, p. 107 (emphasis original).
} 
there are four further embedded rituals acting as symbols: vows with the joining of hands; the exchange of rings (or giving and receiving of one ring); public proclamation by the priest of their new status with the binding of hands; and the laying-on of hands in blessing. These symbols of marriage are being challenged by narratives of Christian experience and operant theology that offer a wider meaning to marriage than hitherto embraced by the normative theology of the Church of England.

'Mythic stories' offer stability, and 'parabolic stories' mediate or contradict our experience. ${ }^{34}$ In the debate on equal civil marriage, the mythic stories of the normative theology of the Church of England in its official response encounter the parabolic stories of human experience of relationship beyond the boundaries of gender and sexuality. When the two forms of story interact, a new reconciliation can emerge through challenging the familiar to enable a change of perspective. 'Stories are mighty and dangerous, but so are rituals, especially those connected with religious expression. Ritual is one place in our regulated lives where we remember the stories of God that have the power to transform us and take us to a new place'. ${ }^{35}$

The ritual of marriage, whether in a secular or religious context, has powerful stories associated with it. The Church of England's response to the UK Government's proposals asserts that there is only one form of marriage with two routes of ritual, civil or religious. The two routes may offer different meanings because of the stories attached to them and by the couple's choice of a secular or religious ceremony. The Church's resistance to engagement with the parabolic narratives challenging its normative theology is creating a 'hollow ring' to the Christian gospel of God's inclusive love given in Jesus of Nazareth. The Church of England's opposition to same-sex marriage has contributed to the government's proposed solution, to ringfence marriage in the established Church. 'The Government [is] responding

\footnotetext{
${ }^{34}$ Herbert Anderson and Edward Foley, Mighty Stories, Dangerous Rituals: Weaving Together the Human and the Divine (London: Wiley \& Sons, 2001), Chapter 1, 'The Power of Storytelling' cited in Graham et al., Theological Reflection: Sources, p. 127.

${ }^{35}$ Anderson and Foley, in Graham et al., Theological Reflection: Sources, p. 137.
} 
to the Church's wish to see the status quo for the Church of England preserved and accepting... that it is not for the Government and Parliament to determine matters of doctrine'. ${ }^{36}$ The Church's insistence on maintaining the status quo has the likely consequence of Parliament enshrining two different meanings and practices in law, precisely the difference the Church's response summary has argued against. An outcome of the proposed 'quadruple lock' is de jure recognition of the de facto secularization of marriage: civil marriages now outstrip religious marriages by two to one. ${ }^{37}$ The Church's response seeks to hold back the tide, rejecting the government's distinction between religious and civil, 'there is no such distinction in law'. ${ }^{38}$ By ignoring data that over two thirds of marriages are now civil, the Church response fails to recognize that couples are making their own distinction de facto. 'Post-secularism, in which religion is defined outside religious institutions by self-regulating individuals in contexts where they have the possibilities to create their own truths and forms of transcendence, is reshaping the inter-relationship between religion and ethics'. 39

Meanwhile, the proportion of marriages solemnized in the Church of England (23\% in 2010) sustains a context and practice of Christian marriage through an Anglican ceremony. The gradual decrease in Anglican Christian marriage erodes within society the opportunity for 'double intersection', when the sacred story crosses with mundane narratives and personal experience. The Church has an opportunity to choose a constructive, imaginative way forward to review the meaning of marriage through theological engagement, first with the issues of the government's proposals rather than declaring the

\footnotetext{
${ }^{36}$ Church of England, 'Same-sex Marriage and the Church of England, an Explanatory Note', (12 December 2012).

37 Office for National Statistics, 'Marriage in England and Wales (provisional), 2010', (London: Crown copyright, 29 February 2012).

38 Church of England, 'A Response', para. 17.

39 Enda McCaffrey, 'The Sexual and Theological Ethics of Gay Marriage in France: A Dialectic between Autonomy and Universalism', Theology \& Sexuality 12.3 (2006), pp. 263284 (267).
} 
proposals 'unwise' and secondly, by accelerating an active process of listening to the stories being told by faithful Anglican Christians.

There are many clergy and laity within same-sex relationships who are members of supportive Anglican worshipping communities, for whom the Church of England's official response is the turning of a deaf ear. One of the key problems for the future of the Church of England is the difficulty Christians have in hearing each other's stories and recognizing God in different contexts and human lives. Robert Williams notes that the visceral reactions and sense of fear among church people who oppose 'gay marriage' is another expression of 'operational' theology which needs to be brought into the conversation. ${ }^{40}$

George Lindbeck's critique of the polarization between traditionalist and liberal factions of the churches led him to propose a 'postliberal' approach. ${ }^{41}$ George Hunsinger explains that 'where literalism sees the mode of reference for theological language as univocal, and expressivism as equivocal, postliberalism sees it as analogical'. ${ }^{42}$ Lindbeck considers a religion as a language within a particular culture that enables people and communities to learn how to feel, act and think. In this conversation, the locating of the story of marriage within community life and action grounds debate in human society. Lindbeck differentiates between change caused by new feelings and change resulting from a new interpretive scheme arising from, and embodied in, practice and belief: 'religious experiences... result from the new conceptual patterns instead of being their source'. ${ }^{43}$

Regarding marriage, formal theological enquiry can test alternatives: that couples and their supporters are pushing the boundaries for change to gratify feelings; or that there are new conceptual patterns driving the change.

\footnotetext{
40 Robert Williams, 'Toward A Theology for Lesbian and Gay Marriage', Anglican Theological Review 72.2 (Spring 1990), pp. 134-157 (135).

${ }^{41}$ George Lindbeck, The Nature of Doctrine (London: SPCK, 1984).

42 George Hunsinger, 'Postliberal theology', in Kevin J Vanhoozer (ed.), The Cambridge Companion to Postmodern Theology (Cambridge: Cambridge University Press, 2003), p. 47.

43 Lindbeck, The Nature of Doctrine, p. 39.
} 
A postliberal approach engages with research and insights from a range of academic disciplines, including social sciences and anthropology, to aid theological reflection in a particular context. The Church of England's parish context offers a varied operant theology of embodied, embedded practice for a potentially rich dialogue of espoused and normative theologies. To break through the established pattern of polarized opposing campaigning groups, the Church of England can choose to move forward by listening to insights from research and from practice.

\subsection{Issues in the Debate}

The Church's response that equal civil marriage 'will affect marriage for all' is based on 'a conviction that the consequences of change will not be beneficial for society as a whole'. ${ }^{44}$ The response uses negative language, asserting 'we believe that redefining marriage to include same-sex relationships will entail a dilution in the meaning of marriage' with the clear implication that this is unwelcome. There is no consideration that to 'include same-sex relationships' will end exclusion and discrimination for real people who experience rejection by churches: 'queer Christians have never been, and still are not considered by many others, to be members of the Body of Christ'. ${ }^{5}$ 'In fundamentalist contexts, principles are more important than people;'46 and 'most cultural discourse about sexuality is fear-based, but religious discourse is often the most blatantly negative'. ${ }^{47}$ The Church's response excludes from marriage people being defined not by their rich humanity but solely by their sexuality.

\footnotetext{
${ }^{44}$ Church of England, 'A Response', para. 8, para. 13.

${ }^{45}$ Robin Hawley Gorsline, 'A Queer Church, Open to All', Union Seminary Quarterly Review, 57.1-2 (2003), pp. 46-66 (46).

${ }^{46}$ Antje Jackelén, '(Homo)Sexuality--Perspectives from Church, Society, and Theology',

Currents in Theology and Mission 29.4 (August 2002), pp. 265-272 (266).

47 Gorsline, 'A Queer Church, Open to All', p. 57.
} 
The debate in the USA illuminates some of the legal issues. ${ }^{48}$ The US Supreme Court has challenged opponents of gay marriage to prove that legalizing marriage for homosexual couples would damage marriage. Machacek and Fulco write:

Once moral objection and prejudice have been rejected as legitimate bases of law-making, bans on same-sex marriage stand on much narrower grounds. Specifically those who oppose such marriages must argue either that withholding marriage licenses [sic] from same-sex couples furthers some state interest other than moral disapproval or that granting the license would cause some demonstrable harm to others or to institutions the law protects. The gay marriage ban, in other words, must have a rational basis. ${ }^{49}$

The authors continue, 'this emergent, constitutional-legal language of public discourse represents a significant departure from the language of Protestant consensus that... once served in the public discourse'. The gay marriage debate in the USA is 'a battle for sovereignty over public discourse and a battle over whether moral autonomy or moral absolutism will prevail in American public life'. ${ }^{50}$ The shift in the public debate in England echoes the shift in the public discourse of the United States. The shift in the USA 'amounts to a loss of sovereignty by Christianity in American public life' through an assertion not of special rights for the gay and lesbian community but 'rights in which all members of the political community, gay and straight, have a stake'. The debate on equal civil marriage in Parliament clearly shows the loss of sovereignty by Christianity in England, including by the Established Church. By explicitly excluding the Church of England from the legislation, the government has taken the Church's opposition seriously. This does not need to be the end of the debate and the Church has the opportunity to engage urgently with the issues arising.

\footnotetext{
48 All marriages in the USA are civil. Courts cases: Colorado (1996) and Massachusetts (2003). David W. Machacek and Adrienne Fulco, 'The Courts and Public Discourse: The Case of Gay Marriage', Journal of Church and State 46.4 (Autumn 2004), pp. 767-785.

49 Machacek and Fulco, 'The Courts and Public Discourse: The Case of Gay Marriage', pp. 776-777.

50 Machacek and Fulco, 'The Courts and Public Discourse: The Case of Gay Marriage', pp. 784-785
} 
Underlying the debate is the question of who chooses to marry. National statistics show that $80 \%$ of couples choose to cohabit for several years ${ }^{51}$ before they marry ${ }^{52}$ and that the fastest growing type of family with children is those who cohabit. ${ }^{53}$ However, the evidence is that cohabitation is not a long-term lifestyle choice for the majority and that most parents marry, often after the birth of their first child. ${ }^{54}$ Cohabitation may be a 'marriage firewall' in which to try out a relationship, which has had the effect of stabilizing the divorce rates within the first years after marriage. ${ }^{55}$ In society, there has been little stigma since the 1970 s for those who cohabit ${ }^{56}$ and many people believe that cohabitation is a 'common law marriage' even though such a status does not exist in England'. ${ }^{57}$ The Church's official teaching on sexual relationships ${ }^{58}$ is out of step with the reality of the majority who cohabit, most of whom choose to marry later on. There remains a desire for stability in an ideal of marriage aspired to by couples, supported by $81 \%$ of the same-sex couples who replied to the government's consultation who expressed a desire to marry. The same percentage preferred the option of civil marriage to civil partnership and also wished to have an additional ceremony for civil partners who marry subsequently. ${ }^{59}$

The Church of England has a significant role in the celebration of over one fifth of marriages and had direct contact with 54,700 couples for preparation in 2010.60 This opportunity offers couples and parish priests discussion

\footnotetext{
${ }^{51}$ Office for National Statistics, 'Short Report: Cohabitation in the UK, p. 3.

52 Éva Beaujouan and Máire Ní Bhrolcháin, 'Cohabitation and marriage in Britain since the 1970s', Population Trends 145 (Autumn 2011), p.10 and p.18.

53 Office for National Statistics, 'Families and Households in England and Wales 2011', (30

January 2013), p. 10 and Office for National Statistics, 'Short Report: Cohabitation in the UK, p. 1.

54 Beaujouan and Bhrolcháin, 'Cohabitation and marriage', p. 13 and p. 10.

55 Beaujouan and Bhrolcháin, 'Cohabitation and marriage', p. 19 and pp. 14-15.

56 Beaujouan and Bhrolcháin, 'Cohabitation and marriage', p. 2.

57 Office for National Statistics, 'Short Report: Cohabitation in the UK', p. 2.

58 'Sexual intercourse, as an expression of faithful intimacy, properly belongs within marriage exclusively', in Church of England, 'Civil Partnerships', para. 4.

${ }^{59}$ Government Equalities Office, 'Equal Marriage: The Government's Response', p. 17, para. 4.

60 Office for National Statistics, 'Marriage in England and Wales (provisional), 2010', (29

February 2012), p. 6.
} 
about marriage in a Christian ceremony. As a priest exploring the meaning of marriage through the Common Worship Marriage Service, ${ }^{61}$ an operant theology of marriage emerges. In my parish experience of preparation, couples are seeking marriage based on mutual equality, celebrating their relationship as two equal people. The Common Worship Marriage service, with the underlying scriptural references embedded within it, can be interpreted by priest and couple as a union of two people before God, both equally loved by God, echoed in a reciprocal love with their spouse. Since my own marriage in 1981 with the Alternative Service Book 1980 liturgy, I have been a guest at only one marriage according to the Book of Common Prayer 1662 and one according to the 1928 rite. Throughout 15 years since ordination to the priesthood I have never been asked to use either of those orders of service. ${ }^{62}$ This means that when the Church of England argues from the Book of Common Prayer, ${ }^{63}$ there is a gap with the training and parish experience of many clergy and their parishioners who have experienced services since liturgical reform in 1980. A marriage of equals is the expectation of heterosexual couples marrying in the Church of England, in my experience, where gender is no longer the only determining factor in future roles within the marriage, such as childcare and primary earning. The operant theology of equal heterosexual marriage recognizes that there have been significant changes in couples' expectations, expressed in discussions with their priest. The couple's experience is often based on cohabitation, including the birth and care of one or more children.

The three benefits of marriage to society listed by the Church of England's response were: to promote mutuality; to promote fidelity; and to recognize biological complementarity with the possibility for many of procreation. ${ }^{64}$ The first two characteristics are increasingly recognized as applicable for samesex relationships, including by the Church of England: 'same-sex

\footnotetext{
61 The Archbishops' Council, Common Worship: Pastoral Services, pp. 102-134.

62 I have prepared for approximately 140 marriages in eight parishes in four dioceses of the Church of England.

${ }^{63}$ Church of England, 'A Response', para. 2 and para. 7.

${ }^{64}$ Church of England, 'A Response', para. 6.
} 
relationships often embody genuine mutuality and fidelity, two of the virtues which the Book of Common Prayer uses to commend marriage'. ${ }^{65}$ Couples, including some who are of the same sex, aspire to the public, lawful union of marriage, to celebrate the mutual relationship of love they have discovered and to commit themselves to an ideal of life-long faithfulness to one another. Scriptural narratives which give Christian meaning to marriage describe a self-giving divine love, embodied in Jesus and indwelling in Spirit. Narratives of divine faithfulness through Judeo-Christian scriptures and tradition encourage God's people to work through the tensions of relationships, including marriage. For many couples who approach their Anglican parish church for marriage, there is an underlying ideal of marriage: that their love will grow and stand the tests of time; that they will be able to keep their vows; that their public vows recognize and celebrate their new status as a couple in society; that somehow God's blessing will help them along their way; and that there is something sensed as 'sacred' in their experience of loving. These hopes are surfacing for some couples in same-sex relationships whose experience of loving is challenging the Church of England. ${ }^{66}$

The third 'benefit' recognized by the Church of England's response is 'biological complementarity with the possibility for many of procreation'. ${ }^{67}$ The Church of England's assumption that biological complementarity is a central characteristic of humanity influences the debates on women and homosexual people as ordained priests and bishops and the debate on gender in marriage relationships. ${ }^{68}$ The Church's response to the government reflects this assumption and fails to acknowledge that biological complementarity is a theory based on a binary evaluation of sex. ${ }^{69}$ The response argues that 'to remove from the definition of marriage this essential complementarity is to lose any social institution in which sexual difference is

\footnotetext{
65 Church of England, 'A Response', para. 9.

${ }^{66}$ Changing Attitude, 'Submission', paras. 1.3 and 1.4.

${ }^{67}$ Church of England, 'A Response', para. 6.

68 Methuen, 'Marriage: one man and one woman?'

${ }^{69}$ Adrian Thatcher, God, Sex and Gender (Chichester: Wiley-Blackwell, 2011), pp. 6-14.
} 
explicitly acknowledged'70 but the theory of essential complementarity risks the reduction of human difference to biological function and has been widely critiqued.

Theological debate on gender began in 1960 with early feminist theologian Valerie Saiving, ${ }^{71}$ and continued in the 'second wave' of feminism: 'where we once thought of sexuality as a biological given of male and female and gender as the social construction of norms, we now question the prior binary assumption of male or female'. ${ }^{72}$ Elizabeth Stuart identifies two sources for the theory of complementarity: an androgynous God, and human gender difference particularly in reproduction, asserting that theology using this theory 'is not found in either the Hebrew Scriptures or the New Testament'. ${ }^{73}$ In a discussion of new ideas about sex and gender, Jeanne Hoeft notes that assertion of a 'natural' normative state as either male or female marginalizes and labels as abnormal people who do not fit chromosomal identity categories of $X X$ or $X Y$ and the one in a thousand babies born whose anatomy makes classification unclear. She reports that ethicist researchers suggest 'that we should not consider sex or gender deviance as a defect but rather as one more way God creates diversity in human life'. Hoeft summarizes, 'normative references to nature, including the natural as that which God created and ordained, often obscure the social construction of what counts as acceptable or as defect and disease in need of correction and treatment'. ${ }^{74}$ Feminist interpretation of the first creation narrative which sought to re-appropriate the equal imaging of $\mathrm{God}$ in both male and

\footnotetext{
${ }^{70}$ Church of England, 'A Response', para. 4.

${ }^{71}$ Elaine Graham, 'Feminist Theory', in Miller-McLemore (ed.), The Wiley-Blackwell Companion to Practical Theology, pp. 193-203 (193).

72 Jeanne Hoeft, 'Gender, Sexism, and Heterosexism', in Miller-McLemore (ed.), The WileyBlackwell Companion to Practical Theology, pp. 412-421 (412).

${ }^{73}$ Lisa Isherwood and Elizabeth Stuart, Introducing Body Theology (Sheffield: Sheffield Academic Press, 1998), p. 56.

${ }^{74}$ Hoeft, 'Gender, Sexism, and Heterosexism', p. 418.
} 
female,${ }^{75}$ has moved to consider 'the slippery fault line between the rhetoric of creation in God's image and the complicated reality of its embodiment'. ${ }^{76}$

Gender essentialists propose that human beings are born either male or female and that their potential biological procreative function fits them from birth for particular roles, defined as complementary. 'Man' was historically understood as one sex with two genders, with the male body as the norm and female as lacking and therefore inferior. ${ }^{77}$ The theory sustained unequal marriage: 'By marriage, the husband and wife are one person in law: that is, the very being or legal existence of the woman is suspended during the marriage, or at least is incorporated and consolidated into that of the husband'. ${ }^{78}$ The two-sex theory of gender emerged in the Enlightenment period, when 'the differences between male and female bodies were read to reflect fundamental, ontological differences between men and women which took women out of the public sphere'. ${ }^{79}$ In the twentieth century, 'it was but a short step to give the two sex doctrine an official title - the doctrine of 'complementarity' of the sexes' with associated assumptions about relationships. ${ }^{80}$

Gender constructivists hold that roles are not wholly defined from birth by biological reproductive sexual function, but are also taught and learnt through human society. Judith Butler shows how Simone de Beauvoir's formulation 'one is not born, but rather becomes, a woman' distinguishes sex as the anatomical difference between bodies whilst gender is acquired

\footnotetext{
75 Phyllis Trible, God and the Rhetoric of Sexuality, (Philadelphia: Fortress Press, 1987), cited in Isherwood and Stuart, Introducing Body Theology, p. 56.

76 Bonnie Miller-McLemore, 'Practising What We Preach: The Case of Women in Ministry.' Practical Theology 2.1 (2009) pp. 45-62, cited by Graham, 'Feminist Theory' in MillerMcLemore, The Wiley-Blackwell Companion to Practical Theology, p. 194.

77 Thatcher, God, Sex and Gender pp. 7-9.

78 Judge William Blackmore (1765), cited in Rebecca Solnit, 'More equal than others', FT Weekend Magazine 513, (25/26 May 2013), pp. 30-31.

79 Tim Hitchcock, 'Redefining Sex in Eighteenth-Centure England,' History Workshop Journal 41, (Spring 1996), pp. 72-90, cited in Isherwood and Stuart, Introducing Body Theology, p. 72. 80 Thatcher, God, Sex and Gender p. 7.
} 
through cultural meaning and form. ${ }^{81}$ Butler argues 'that gender is 'performed', not given'. ${ }^{22}$ Christie Neuger recommends addressing the social construction of gender as theoretical support for thinking about women's identity. ${ }^{83}$ Eugene Rogers writes, 'Difference cannot be reduced to malefemale complementarity, because that would leave Jesus a deficient human being. Jesus did not need a female other half to be fully human'. ${ }^{84}$ Lisa Isherwood and Stuart commend body theology, where theology is through the body not about the body. ${ }^{85}$ Jeanne Hoeft discusses the two positions of difference and equality, citing Bonnie Miller-McLemore and Herbert Anderson who argue 'for equality without sameness' and advocate engagement in gender analysis to move toward 'the diversity and justice of God's creative love'. Hoeft notes that 'the biological is not fully distinct from the socially constructed', ${ }^{86}$ and continues that 'sexual difference between men and women is not as big as the similarities between them'. ${ }^{87}$ This leads to the 'pragmatic question, 'What difference should the gender differences make?"88 Elaine Graham questions, "What ways of life or of doing gender are in keeping with Christian values?'89 The Church can choose to engage constructively with these questions in the debate on equal marriage.

Changes in patterns of procreation have created a revolution in attitudes and choices since the 1960s. Artificial contraception is accepted by the Church of England as a responsible choice. The separation of sexual intercourse from conception reduces unwanted pregnancy, protects from transmitted

\footnotetext{
${ }^{81}$ Judith Butler, 'Sex and Gender in Simone de Beauvoir's Second Sex', Yale French Studies 72 (1986), pp. 35-49 (35).

82 Hoeft, 'Gender, Sexism, and Heterosexism', p. 418.

83 Hoeft, 'Gender, Sexism, and Heterosexism', p. 415.

${ }^{84}$ Eugene F Rogers, Jr, 'Sanctified Unions', Christian Century 121.12 (June 2004), pp. 26-29 (29).

85 Isherwood and Stuart, Introducing Body Theology, p. 22.

${ }^{86}$ Bonnie Miller-McLemore and Herbert Anderson, 'Gender and Pastoral Care,' (1995), in Pamela Couture and Rodney Hunter (eds.) Pastoral Care and Social Conflict, (Nashville: Abingdon Press, 1995), pp. 99-113, (102), cited in Hoeft, 'Gender, Sexism, and Heterosexism', p. 415.

${ }^{87}$ Hoeft, 'Gender, Sexism, and Heterosexism', p. 415

88 Miller-McLemore and Anderson, 'Gender and Pastoral Care,' p.106, cited in Hoeft, 'Gender, Sexism, and Heterosexism', p. 416.

${ }^{89}$ Hoeft, 'Gender, Sexism, and Heterosexism', p. 416.
} 
diseases and recognizes sexual fulfilment for pleasure. It also recognizes an option, rather than a requirement, for the possibility of biological procreation within marriage, thereby opening a route to the extension of the meaning of marriage to same-sex couples. The lack of capability or intention to procreate is already recognized and accepted in Church of England marriage. The balance of family life has changed for both parents and there is now a range of types of family within England. 'The sheer diversity of current family arrangements is historically unique'90 and assisted reproduction has become possible for couples and individuals. These social changes have shifted the view of marriage as the sole context for sexual relationship so that by 2010 , a similar proportion of cohabiting parents as married parents cared for dependent children (38\% and 39\%). ${ }^{91}$ Such changes make the third benefit of marriage defined by the Church's response void as an essential requirement and open up the possibility of recognizing diverse patterns of parenting to couples regardless of gender.

Feminist theology critiques 'patriarchy, a gendered hierarchy in which men dominate and use their power to control women'.92 Jeanne Hoeft builds on liberation and feminist theologies: 'queer theorists argue that the sex binary of male and female is not inherently given but is instead a social construction to support heterosexual hegemony. Male and female are thus politically assigned categories of identity'. ${ }^{93}$ James Poling's theological anthropology leads him to assert that 'both men and women need God images that challenge the prevailing image of an authoritarian parent'. ${ }^{94}$ Twenty years ago Bonnie Miller-McLemore proposed the 'living human web' as the primary subject matter for pastoral theology, in continuity with but moving on from study of 'the living human document'. She identifies a 'communal contextual' paradigm that 'attends to the impact of social forces and proposes changes

\footnotetext{
${ }^{90}$ Beaujouan and Bhrolcháin, 'Cohabitation and marriage', p. 18.

91 Office for National Statistics, 'Short Report: Cohabitation in the UK, p. 4.

92 Hoeft, 'Gender, Sexism, and Heterosexism', p. 414.

${ }^{93}$ Hoeft, 'Gender, Sexism, and Heterosexism', p. 419.

94 Hoeft, 'Gender, Sexism, and Heterosexism', p. 414.
} 
in social policy as well as in individuals and congregations'. ${ }^{95}$ Marcella Althaus-Reid offers "an "indecent theology" of a "Queer God," who is "a stranger at the gate; a God that has been excluded by sexual and economic normativities"'. ${ }^{96}$ Hoeft argues:

that practical theologians must engage these queer discussions because they bring a unique perspective. If practical theology hopes to shape the church, we must interrogate how we have used gender as a category and perpetuated a false sex/gender distinction and sexual dualism, now under question.

People with power in any relationship or context are capable of dominating those with less power, for a range of complex reasons, so that inequality in relationships and structures is pervasive. Archie Smith describes the effect: 'the totalizing power of a dominant culture reproduces itself through 'particular power arrangements and relational patterns of discrimination' at the expense of those it constitutes as marginal - psychically as well as materially - as it also privileges others'. ${ }^{97}$ Far from being change which is 'deeply unwise', Solnit sees benefits of same-sex marriage to heterosexual couples and wider society,

because a marriage between two people of the same gender is inherently egalitarian - one partner may happen to have more power in any number of ways, but for the most part it's a relationship between people who have equal standing and who are free to define their roles themselves... No hierarchical tradition underlies their union. Some people have greeted this with joy. ${ }^{98}$

To engage with the current debate on equal marriage requires informed research and listening from the Church of England: to the stories of people within who aspire to Christian equal marriage (heterosexual and

\footnotetext{
95 Hoeft, 'Gender, Sexism, and Heterosexism', p. 413.

96 Hoeft, 'Gender, Sexism, and Heterosexism', p. 419.

97 Nancy J. Ramsay, 'Emancipatory Theorgy and Method', in Miller-McLemore (ed.), The Wiley-Blackwell Companion to Practical Theology, pp. 183-192 (186).

98 Solnit, 'More equal than others', p. 31.
} 
homosexual); and to the academy where theologians have been contributing for fifty years. Hoeft lays down a challenge: 'Practical theologians must take up these questions and seek answers that account for the real people who struggle to find an authentic and meaningful life on the boundaries of church and society'. ${ }^{99}$ Rogers adds a warning, 'Not to celebrate same-sex weddings may also be morally dangerous'. ${ }^{100}$

\section{Conclusion}

The asymmetry of voices in the church privileges the normative theology of the Church of England's tradition over operant 'subaltern' voices arising from insights based in particular human relationships and local parish practice. ${ }^{101}$ This article has sought to offer a voice which begins to sing with hope and delight, ${ }^{102}$ that there are new possibilities emerging in embodied human relationships. By intentionally holding an open horizon for human possibility, I, as a parish priest, seek to listen to the stories of people within my pastoral practice as they resonate with the story of God, among us in Jesus and in Spirit. This contemplative attention in conversation with scholarship, seeks through formal theological endeavour to inform our operant theology, find a new language for our espoused theology and foster change in the normative theology of our tradition in the Church of England.

The possibility of Christian equal marriage as an Anglican ideal opens further avenues for enquiry and research. In liturgy we could swiftly open the present barriers to the blessing of people in civil unions and discover God's grace in their Christian lives. We can work towards new understandings of the meaning of equal marriage through contemplative attention: an approach of humility, openness and sustained engagement with peoples' stories, listening for the hum of harmony with God's stories; to discover new insights into human being. In formal theological study, we as English Anglicans may

\footnotetext{
99 Hoeft, 'Gender, Sexism, and Heterosexism', p. 419.

100 Rogers, 'Sanctified Unions', p. 29.

101 Cameron et al., Talking about God in practice', pp. 59-60.

102 M. Midgley in Pattison, 'Practical Theology', p. 281.
} 
re-engage with the experience and practice of human relationships in our contemporary context. Instead of marginalizing ourselves by the perceived constant negativity of official pronouncements, the Church of England, still the established church, could offer a theology of the rich complexity of Christian human living to our society. A vision of a new Anglican ideal of Christian equal marriage may emerge: with equal access and equality within; as we embrace change of practice and change through practice. ${ }^{103}$ Far from being of marginal interest to a small proportion of our society, a new vision of marriage through formal theological engagement can transform our theology at every level, operant, espoused and normative. Stephen Pattison asserts that 'Christianity, together with the theology that helps it to understand itself and the world, is potent, exotic stuff. ${ }^{104}$ An emerging theology of equal marriage has, I contend, the potential to provide 'a bigger vision and valuefilled worldview of what might be possible in creation'105 and may transform the Church of England's theology, practice and our relationship with the society and people we serve.

${ }^{103}$ Cameron et al., Talking about God in Practice, p. 59.

104 Pattison, 'Practical Theology', p. 283.

${ }^{105}$ Pattison, 'Practical Theology', p. 283. 